\title{
Temporal variation in the structure of intertidal assemblages following the removal of sewage
}

\author{
P. Archambault ${ }^{1, *}$, K. Banwell ${ }^{2}$, A. J. Underwood ${ }^{1}$ \\ ${ }^{1}$ Centre for Research on Ecological Impacts of Coastal Cities, Marine Ecology Laboratories A11, University of Sydney, \\ Sydney, New South Wales 2006, Australia \\ ${ }^{2}$ New South Wales Department of Environmental Health, North Sydney, New South Wales 2059, Australia
}

\begin{abstract}
Following the closure of 2 outfalls, changes in the number of species and abundance of intertidal organisms at 2 decommissioned outfalls were compared with control (sewage outfalls that remained in operation) and reference (natural) areas. Two intertidal levels (mid- and low-shore) were sampled 5 times over 2 yr following the closure of these outfalls. It was proposed that the number of species would increase and the abundance of green algae would decrease through time at the decommissioned outfalls, while no noticeable changes in the number of species and the abundance of green algae were predicted at the reference and control locations. The 4 outfalls (2 decommissioned and 2 controls) were analysed separately with an asymmetrical ANOVA to identify differences between the outfall and the average of their 2 respective reference locations. Non-metric multidimensional scaling ordination using Bray-Curtis similarity was used to identify differences between outfalls and reference locations in the structure of the assemblages at the 2 heights on the shore. During the first (6 mo after closure) and second sampling period, fewer species and greater abundance of green algae were observed at every outfall than at their respective reference locations in low-shore areas. In the subsequent sampling periods, the number of species at the decommissioned outfalls increased through time while there were consistently fewer species at the control outfalls. The opposite pattern was observed for the abundance of green algae (i.e., decreases through time at the decommissioned outfalls). Assemblages at control outfalls never clustered with their reference locations. At midshore levels, no pattern was observed at any sampling date. Furthermore, at the first time of sampling, the number of species was not smaller at the outfalls than at reference locations. These results suggest that sewage outfalls have little impact on the number of midshore species. The results of univariate analysis were similar to those from multivariate analyses. Assemblages of species in low-shore areas at the decommissioned outfalls were different from those at reference locations at the first sampling date, but became more similar by the last sampling date. Some exceptions were observed at the site closest to the point of discharge. Again no differences in abundances of organisms were observed at any time for any outfall. The results showed a recovery of the benthic assemblages in the low-intertidal zone after the closure of 2 sewage outfalls. Furthermore, this study supports the importance of using more than 1 reference and control areas to measure recovery of a site without ambiguity.
\end{abstract}

KEY WORDS: Sewage outfalls $\cdot$ Recovery $\cdot$ Human disturbance $\cdot$ Species richness $\cdot$ Green ephemeral algae $\cdot$ Benthic assemblage $\cdot$ Experimental design

\section{INTRODUCTION}

*Present address: Regional Oceans and Environment Branch, Fisheries and Oceans Canada, Institut Maurice-Lamontagne, 850, Route de la Mer, CP 1000, Mont-Joli, Québec G5H 3Z4, Canada. E-mail: archambaultp@dfo-mpo.gc.ca
Potential impacts of large sewage outfalls on intertidal rocky shore assemblages have been described in the literature (Borowitzka 1972, Littler \& Murray 1975, 
Axelrad et al. 1981, Smith et al. 1981, May 1985, Fairweather 1990, López Gappa et al. 1990, 1993, Bellgrove et al. 1997). Outfalls discharging waste water of varying quality and volume have been shown to alter the structure of nearby assemblages (Borowitzka 1972, Fairweather 1990). Particular types of algae such as ephemeral green algae and animals such as Serpulorbis squamigerus (Littler \& Murray 1975, Brown et al. 1990, Fairweather 1990, Bellgrove et al. 1997) have been described as occurring near outfalls.

Most studies on ecological impacts of sewage on marine assemblages have been comparisons between reference and affected locations (Borowitzka 1972, Littler \& Murray 1975, Brown et al. 1990, Fairweather 1990, Chapman et al. 1995, Bellgrove et al. 1997) or before and after (Before After Control Impact-BACI design, Underwood 1991, 1992, 1994) the start of discharge (Roberts et al. 1998, Ajani et al. 1999, Smith et al. 1999). Relatively few studies have documented the recovery of benthic assemblages following the cessation of a long-standing discharge of sewage (Pearson \& Rosenberg 1978, Smith et al. 1981). In the 32 mo after the cessation of the discharge of sewage into Kaneohe Bay, Hawaii, Smith et al. (1981) observed a large decline in the biomass of benthic animals, especially in the first year. They concluded that the response of those benthic assemblages to the diversion was very rapid. Furthermore, the authors assumed that the major role of the sewage was nutritional rather than toxic. This differs from many other studies, which have concluded that sewage has only negative effects (Fairweather 1990, López Gappa et al. 1990, Roberts et al. 1998).

Few studies have shown the full scale of these changes, with data gathered before the pollution ceased and through sufficient time until no observable differences between the previously polluted sites and reference sites were distinguishable. Further, despite improvements in sampling designs and analytical techniques to measure outcomes of disturbances (Eberhert \& Thomas 1991, Underwood 1992, 1994, 1996), many recent studies (Calcagno et al. 1997, Calcagno et al. 1998, Taylor et al. 1998, Lopez-Rodriguez et al. 1999) remain poorly replicated and proper controls are commonly lacking. Recovery following cessation of a disturbance has to be measured as an interaction in time and space with an appropriate experimental design (Green 1979).

In 1991, 2 large metropolitan shoreline outfalls in the most heavily populated region of Australia (Sydney-Illawarra region) were closed (Otway 1995a). This provided an ideal opportunity for a spatially replicated investigation of the effects of the removal of sewage from rocky intertidal assemblages. This closure had largely been driven by public concerns about human health and the environment. The effects of sewage on intertidal assemblages had been studied at these outfalls before they were decommissioned (Borowitzka 1972, Fairweather 1990). Borowitzka (1972) observed a smaller number of algal species, especially Phaeophyceae and the Rhodophyceae, near an outfall than in reference locations. Green ephemeral algae (Ulvoid), which dominated rocky shores adjacent to outfalls, were studied by Fairweather (1990). The ulvoid mat reached $100 \%$ cover in many places near outfalls and abundances of animals were smaller than at reference locations. Generally, assemblages close to outfalls were dominated by early-stage colonising species.

From these studies and a study of the same locations by Banwell (1996, unpubl. data), it appears that sewage was the dominant factor determining the structure of intertidal assemblages near outfalls. Decommissioning of several local outfalls provided an excellent opportunity to examine this model for different assemblages near outfalls. We had reference locations where there were no outfalls and therefore no sewage. Assemblages in these locations represent background, 'undisturbed' shores, i.e. unaffected by the particular disturbance due to discharge of sewage. Outfalls to be decommissioned can be considered as replicates of the experimental treatment, but were analysed separately and the results compared. Outfalls that continued to discharge sewage provided replicated controls. This allowed tests of specific hypotheses about recovery of biota (to match the current situation in reference areas). The design also unconfounds changes due to decommissioning from any coincident background or natural changes, which would also affect controls. The rationale and logic of this experimental design have been discussed in detail by Chapman (1999) in the context of recovery of disturbed habitats.

\section{METHODS}

Study sites. Four shore-line outfalls in the Sydney metropolitan region of New South Wales, Australia (Fig. 1) were studied. Two outfalls, North Head and Malabar, were to cease operation with the opening of new deepwater ocean outfalls (Otway 1995a). Two other outfalls at Potter Point and Bellambi, which were to continue to operate and discharge effluent near the shore, were selected as controls. The average (during dry season) daily flows of sewage through North Head, Malabar, Potter Point and Bellambi in 1991 were 295, 475, 46 and $20 \mathrm{Ml} \mathrm{d}^{-1}$, respectively. The 4 outfalls received primary treatment with the exception of Bellembi during the dry season, where the effluent received an additional treatment with chemically 
assisted sedimentation. The depth of the discharge at North Head and Malabar was approximately $7 \mathrm{~m}$ below mean water level and just below the mean low tide level at Potter Point. The discharge pipe at Bellambi was exposed during low tide; effluent was discharged at the sea surface. More detail on sewage at each outfall is available in the Camp, Dresser \& McKee International Inc. (CDM 1989) review and in Otway (1995a). For each region, 2 reference locations were selected to be as similar as possible to the outfall with respect to aspect, wave exposure, slope of the shore and geological features. Wherever possible, they were chosen to be either side of the outfall. The reference locations for North Head and Potter Point were both located north of the outfall (Fig. 1) because of restrictions of access and because there were no suitable locations to the south of the outfalls. Reference locations were approximately 600 and $1000 \mathrm{~m}$ from North Head and 400 and $5000 \mathrm{~m}$ from Potter Point. At Malabar, the reference locations were north and south of the outfall at 1300 and $1000 \mathrm{~m}$, respectively. The north and south references at Bellambi were 300 and $500 \mathrm{~m}$ from the outfall. At 2 tidal heights (low- and midshore), 3 sites $(4 \times 4 \mathrm{~m})$ were randomly selected within each location. Sites were marked to ensure that the same areas were sub-sampled independently at later times. These sites were between 25 and $50 \mathrm{~m}$ from the point of discharge on each shore. Sampling was done 5 times between 1991 and 1993 (July/August 1991, 1992 and 1993, October/November 1991 and April/May 1992). Seasonal differences could not be analysed because there was only 1 sample in each season (Underwood 1993). The first samples were taken 6 mo after the sewage outfall ceased to be discharged. It was not possible to sample earlier because the construction of the new deep-water outfall was completed 10 mo ahead of schedule. During these 6 mo, however, effluent was released from the decommissioned outfalls when repairs and improvements were made. Sampling in July/August 1991 was therefore deemed to be 'before' decommissioning. There was no sampling in July/ August 1991 at Bellambi and no data were collected at the midshore level at this outfall at any time because there was no midshore habitat close to the outfall.

Sampling. Five randomly placed quadrats $(50 \times$ $50 \mathrm{~cm}$ ) were sampled for intertidal assemblages at each site at each time. The percentage covers of algae and sessile animals in each quadrat were estimated from 100 regularly spaced points. Organisms under each point were recorded, and organisms seen but not recorded under a point were noted as present. Canopy-forming species were sampled first, then were moved to 1 side to sample the understorey. Organisms were identified to the greatest taxonomic resolution possible, but many groups, particularly red algae,

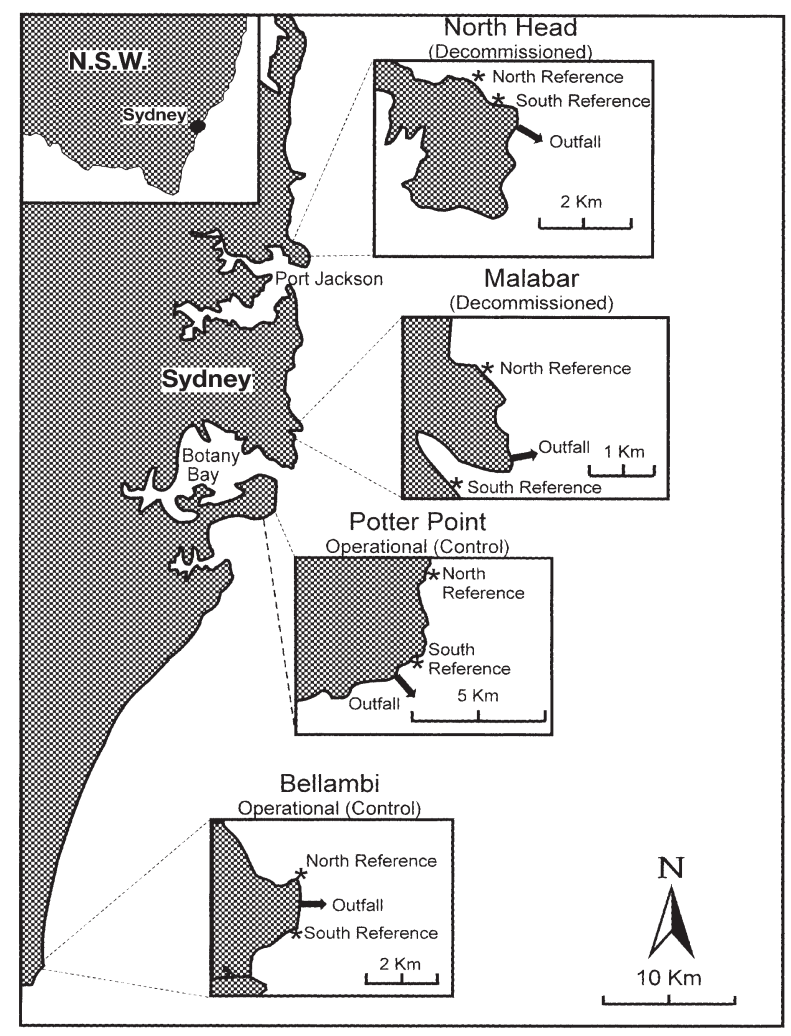

Fig. 1. Map of the coast of Sydney, New South Wales (NSW), Australia, showing the 4 regions and the positions of the locations sampled. * Reference locations; arrows: outfalls

were hard to identify because individual species are not well known or documented in Australia (Clayton \& King 1990). These groups were given common names to identify the particular morphotaxa. Specimens were collected to confirm field identifications. Motile animals found within the quadrats were all identified to species level and the numbers of individuals were recorded. Where numbers were too large to count, 5 small sub-quadrats $(4.5 \times 4.5 \mathrm{~cm})$ were counted and the numbers multiplied up to the area of the quadrat. No attempt was made to count small fast-moving animals such as amphipods.

Statistical analysis. Univariate analyses: Differences in the mean number of species in the low (Table 1) and midshore (Table 2) habitats and the mean percentage cover of green algae (Table 3 ) were analysed using an asymmetrical design to identify differences between the outfall and the average of the 2 reference locations (Underwood 1993, 1994, Glasby 1997). Recovery was measured as an interaction in time and space between the 2 decommissioned outfalls and their respective reference locations. Data for the 4 regions were analysed separately. Variances were homogeneous in all analyses (determined using 
Table 1. Asymmetrical ANOVA comparing the total number of species in low-shore habitats at different times at 3 sites at 1 outfall and 2 reference locations. The data from North Head were $\ln (x+1)$ transformed. $n s: p>0.05 ;{ }^{*} p<0.05$; ${ }^{* *} p \leq 0.01$; ${ }^{* * *} \mathrm{p} \leq 0.001$

\begin{tabular}{|c|c|c|c|c|c|c|c|c|c|c|c|c|c|c|}
\hline \multirow[t]{3}{*}{ Source of variation } & \multirow[b]{3}{*}{ df } & \multicolumn{6}{|c|}{ Decommissioned outfalls } & \multicolumn{7}{|c|}{ Operational outfalls (controls) } \\
\hline & & \multicolumn{3}{|c|}{ North Head } & \multicolumn{3}{|c|}{ Malabar } & \multicolumn{4}{|c|}{ Potter Point } & \multicolumn{3}{|c|}{ Bellambi } \\
\hline & & MS & $F$ & $\mathrm{p}$ & MS & $F$ & $\mathrm{p}$ & MS & $F$ & $\mathrm{p}$ & df & MS & $F$ & $\mathrm{p}$ \\
\hline Location (L) & 2 & & & & & & & & & & 2 & & & \\
\hline Outfall vs reference & 1 & 24.94 & 10.7 & ns & 2954.24 & 19.96 & ns & 8862.24 & 167.82 & $*$ & 1 & 6084.44 & 1267.59 & * \\
\hline Between references & 1 & 2.33 & 20.44 & $*$ & 148.01 & 2.09 & ns & 52.81 & 3.12 & ns & 1 & 4.8 & 0.07 & ns \\
\hline Time $(\mathrm{T})$ & 4 & 1.19 & 2.11 & ns & 115.57 & 1.06 & ns & 102.47 & 5.09 & $*$ & 3 & 14.16 & 2.07 & $\mathrm{~ns}$ \\
\hline $\mathrm{T} \times \mathrm{L}$ & 8 & & & & & & & & & & 6 & & & \\
\hline $\mathrm{T} \times$ outfall vs reference & 4 & 0.84 & 2.85 & ns & 149.72 & 2.21 & ns & 39.62 & 2.21 & ns & 3 & 3.24 & 0.31 & $\mathrm{~ns}$ \\
\hline $\mathrm{T} \times$ between references & es 4 & 0.29 & 5.2 & ** & 67.84 & 1.87 & ns & 0.64 & 0.04 & ns & 3 & 10.4 & 0.86 & $\mathrm{~ns}$ \\
\hline Sites (location) & 6 & & & & & & & & & & 6 & & & \\
\hline Sites (outfall) & 2 & 9.14 & 176.84 & *** & 341.85 & 56.08 & $* * *$ & 95.52 & 14.62 & ${ }^{* * *}$ & 2 & 120.98 & 69.05 & ${ }^{* * *}$ \\
\hline Sites (references) & 4 & 0.11 & 2.2 & ns & 70.81 & 11.62 & $* * *$ & 16.91 & 2.59 & ${ }^{*}$ & 4 & 219.11 & 22.66 & $* * *$ \\
\hline $\mathrm{T} \times \operatorname{sites}(\mathrm{L})$ & 24 & & & & & & & & & & 18 & & & \\
\hline $\mathrm{T} \times$ sites (outfall) & 8 & 0.61 & 11.75 & $* * *$ & 21.75 & 3.57 & $* * *$ & 8.25 & 1.26 & $\mathrm{~ns}$ & 6 & 0.84 & 0.26 & $\mathrm{~ns}$ \\
\hline $\mathrm{T} \times$ sites (references) & 16 & 0.06 & 1.09 & ns & 36.25 & 5.95 & $* * *$ & 17.27 & 2.64 & *** & 12 & 12.06 & 3.8 & ${ }^{* * *}$ \\
\hline Residual & 180 & 0.05 & & & 6.1 & & & 6.53 & & & 144 & 3.17 & & \\
\hline Total & 224 & & & & & & & & & & 179 & & & \\
\hline
\end{tabular}

Cochran's $C$-test) except in 2 cases where the total number of species in the low- and midshore for North Head were $\ln (x+1)$ transformed to achieve homogeneity. In addition, Student-Newman-Keuls (SNK) tests were done on appropriate means, so that differences could be identified in relation to the specified hypotheses.

Multivariate analyses: Differences in the structure of whole assemblages among the 3 locations in each region were identified by non-metric multi-dimensional scaling (nMDS) ordination on untransformed data, using the Bray-Curtis similarity measure (Clarke 1993). The centroid of the 5 quadrats in each site was used to evaluate the dissimilarity. Following the univariate analyses, it was decided to use only July/ August 1991 and July/August 1993 in the analyses on total number of species in the low- and midshore (see 'Results' section. Analysis of similarities (ANOSIM) testes for differences in the composition of assemblages and is a procedure that cannot handle experimental designs with more than 2 factors (Clarke 1993) and therefore was not used here. To test predictions

Table 2. Asymmetrical ANOVA comparing the total number of species in the midshore habitats at 5 different times, at 3 sites at 1 outfall and 2 reference locations for each outfall sampled. The data from North Head were $\ln (x+1)$ transformed. ns: $p>0.05$; ${ }^{*} \mathrm{p}<0.05 ;{ }^{* *} \mathrm{p} \leq 0.01 ;{ }^{* * *} \mathrm{p} \leq 0.001$

\begin{tabular}{|c|c|c|c|c|c|c|c|c|c|c|}
\hline \multirow[t]{3}{*}{ Source of variation } & \multirow[b]{3}{*}{ df } & \multicolumn{6}{|c|}{ Decommissioned outfalls } & \multirow{2}{*}{\multicolumn{3}{|c|}{$\begin{array}{l}\text { Operational outfalls (controls) } \\
\text { Potter Point }\end{array}$}} \\
\hline & & \multicolumn{3}{|c|}{ North Head } & \multicolumn{3}{|c|}{ Malabar } & & & \\
\hline & & MS & F & $\mathrm{p}$ & MS & $F$ & $\mathrm{p}$ & MS & $F$ & $\mathrm{p}$ \\
\hline Location (L) & 2 & & & & & & & & & \\
\hline Outfall vs reference & 1 & 2.81 & 10.43 & ns & 3.38 & 0.08 & ns & 0.27 & 0.02 & ns \\
\hline Between references & 1 & 0.27 & 1.21 & ns & 41.61 & 5.97 & $\mathrm{~ns}$ & 12.33 & 2.42 & $\mathrm{~ns}$ \\
\hline Time (T) & 4 & 1.98 & 0.91 & ns & 33.62 & 0.65 & $\mathrm{~ns}$ & 9.47 & 0.64 & $\mathrm{~ns}$ \\
\hline $\mathrm{T} \times \mathrm{L}$ & 8 & & & & & & & & & \\
\hline $\mathrm{T} \times$ outfall vs reference & 4 & 1.04 & 0.31 & ns & 93.26 & 9.88 & ${ }^{*}$ & 14.49 & 0.98 & $\mathrm{~ns}$ \\
\hline $\mathrm{T} \times$ between references & 4 & 3.3 & 23.96 & ${ }^{* * *}$ & 9.44 & 1.3 & $\mathrm{~ns}$ & 14.74 & 2.3 & $\mathrm{~ns}$ \\
\hline Sites (location) & 6 & & & & & & & & & \\
\hline Sites (outfall) & 2 & 8.03 & 134.98 & ${ }^{* * *}$ & 31.21 & 18.1 & ${ }^{* * *}$ & 239.77 & 120.69 & ${ }^{* * *}$ \\
\hline Sites (References) & 4 & 0.22 & 3.72 & ${ }^{* *}$ & 6.97 & 4.04 & ${ }^{* *}$ & 5.09 & 2.56 & * \\
\hline $\mathrm{T} \times \operatorname{sites}(\mathrm{L})$ & 24 & & & & & & & & & \\
\hline $\mathrm{T} \times$ sites (outfall) & 8 & 1.52 & 25.4 & ${ }^{* * *}$ & 5.21 & 3.02 & ${ }^{* *}$ & 24.64 & 12.4 & ${ }^{* * *}$ \\
\hline $\mathrm{T} \times$ sites (references) & 16 & 0.14 & 2.3 & ** & 7.24 & 4.2 & ${ }^{* * *}$ & 6.41 & 3.23 & ${ }^{* * *}$ \\
\hline Residual & 180 & 0.06 & & & 1.72 & & & 1.99 & & \\
\hline Total & 224 & & & & & & & & & \\
\hline
\end{tabular}




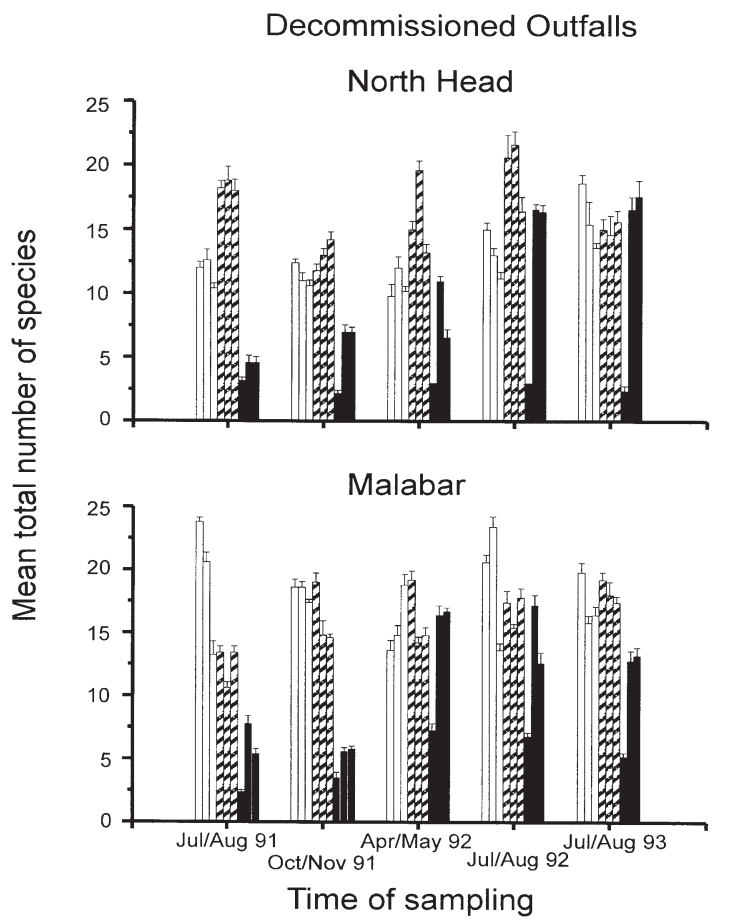

Decommissioned Outfalls
Operational Outfalls (Control)
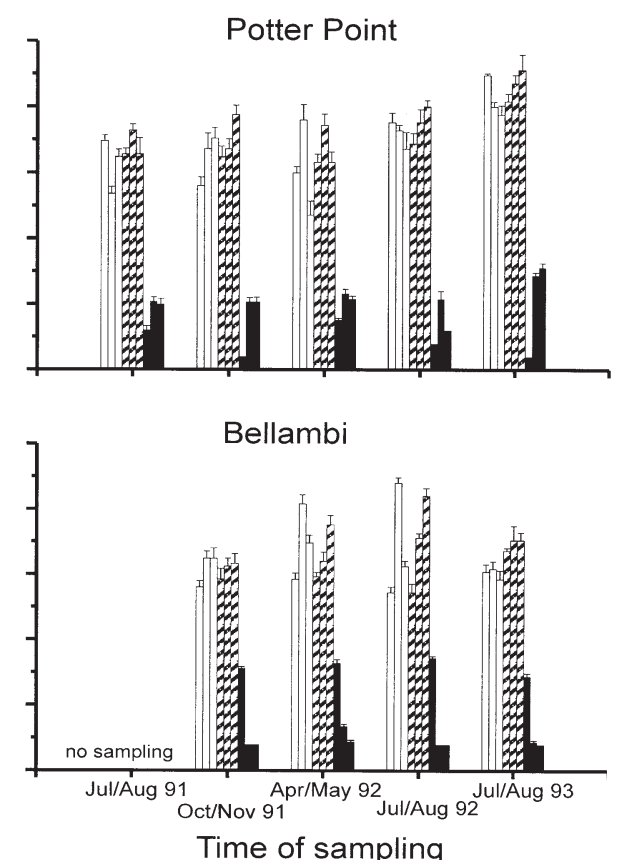

Fig. 2. Mean (+SE) number of species through time in low-shore habitats for each site at the outfall (black column), and north (white column) and south (hashed column) reference locations. North Head and Malabar are the 2 experimental regions, i.e. where the outfall was decommissioned. No data could be collected at Bellambi in July/ August 1991. The site closest to the point of discharge at the outfalls is the left black column for each sampling time about the assemblages and interactions through time and space, percentage dissimilarities were calculated between locations for the 2 times. Percentage dissimilarities were evaluated only for the nMDS ordinations showing a specific pattern. If the 2 decommissioned outfall locations were recovering through time, there should be a decrease in percentage dissimilarities between the outfall and the reference locations through time. This would indicate that assemblages at outfall locations were becoming more similar to those at the reference locations. It was predicted that the non-decommissioned outfall locations were going to stay largely dissimilar from their reference locations through time. One site at each of North Head and Malabar outfalls (the site closest to the point of discharge on each shore) had to be excluded from the evaluation of the percentage dissimilarity because the site was considerably disturbed by recreational fishermen (Banwell 1996) throughout the study. Banwell (1996) observed that fishermen kept these 2 outfall sites clear

Table 3. Asymmetrical ANOVA comparing the total percentage cover of green algae in low-shore habitats at different times at 3 sites at 1 outfall and 2 reference locations for each outfall sampled. ns: $p>0.05 ;{ }^{*} p<0.05 ;{ }^{* * *} \mathrm{p} \leq 0.001$

\begin{tabular}{|c|c|c|c|c|c|c|c|c|c|c|c|c|c|c|}
\hline \multirow{3}{*}{ Source of variation } & \multirow[b]{3}{*}{ df } & \multicolumn{6}{|c|}{ Decommissioned outfalls } & \multicolumn{7}{|c|}{ Operational outfalls (controls) } \\
\hline & & \multicolumn{3}{|c|}{ North Head } & \multicolumn{3}{|c|}{ Malabar } & \multicolumn{4}{|c|}{ Potter Point } & \multicolumn{3}{|c|}{ Bellambi } \\
\hline & & MS & $F$ & $\mathrm{p}$ & MS & $F$ & $\mathrm{p}$ & MS & $F$ & $\mathrm{p}$ & df & MS & $F$ & $\mathrm{p}$ \\
\hline Location (L) & 2 & & & & & & & & & & 2 & & & \\
\hline Outfall vs reference & 1 & 18611.6 & 458.87 & * & 260257 & 7.79 & ns & 1004039 & 92.5 & ns & 1 & 532110 & 277.7 & $*$ \\
\hline Between references & 1 & 40.56 & 0.01 & ns & 33391 & 101.73 & $* * *$ & 10855 & 3.92 & ns & 1 & 1916 & 1.52 & ns \\
\hline Time $(\mathrm{T})$ & 4 & 7644.6 & 1.73 & ns & 22862 & 2.65 & ns & 13206 & 3.97 & $*$ & 3 & 5047 & 1.79 & ns \\
\hline $\mathrm{T} \times \mathrm{L}$ & 8 & & & & & & & & & & 6 & & & \\
\hline $\mathrm{T} \times$ outfall vs reference & 4 & 6698.5 & 3.17 & ns & 12100 & 2.35 & ns & 5079 & 3.24 & ns & 3 & 5337 & 18 & $*$ \\
\hline $\mathrm{T} \times$ between reference & es & 2115.8 & 0.69 & ns & 5139 & 8.17 & $* * *$ & 1570 & 2.48 & ns & 3 & 297 & 0.93 & ns \\
\hline Sites (location) & 6 & & & & & & & & & & 6 & & & \\
\hline Sites (outfall) & 2 & 156226.7 & 194.61 & $* * *$ & 16437 & 31.7 & $* * *$ & 7362 & 17.83 & $* * *$ & 2 & 109997 & 1393 & $* * *$ \\
\hline Sites (references) & 4 & 3967.4 & 4.94 & $* * *$ & 328 & 0.63 & $\mathrm{~ns}$ & 2767 & 6.7 & $* * *$ & 4 & 1257 & 15.92 & $* * *$ \\
\hline $\mathrm{T} \times$ sites $(\mathrm{L})$ & 24 & & & & & & & & & & 18 & & & \\
\hline $\mathrm{T} \times$ sites (outfall) & 8 & 4903.1 & 6.11 & $* * *$ & 8155 & 15.73 & $* * *$ & 1501 & 3.64 & $* * *$ & 6 & 7540 & 95.51 & $* * *$ \\
\hline $\mathrm{T} \times$ sites (references) & 16 & 3045.9 & 3.79 & $* * *$ & 629 & 1.21 & ns & 632 & 1.53 & ns & 12 & 318 & 4.02 & $* * *$ \\
\hline Residual & 180 & 802.8 & & & 518 & & & 413 & & & 144 & 79 & & \\
\hline Total & 224 & & & & & & & & & & 179 & & & \\
\hline
\end{tabular}


Decommissioned Outfalls

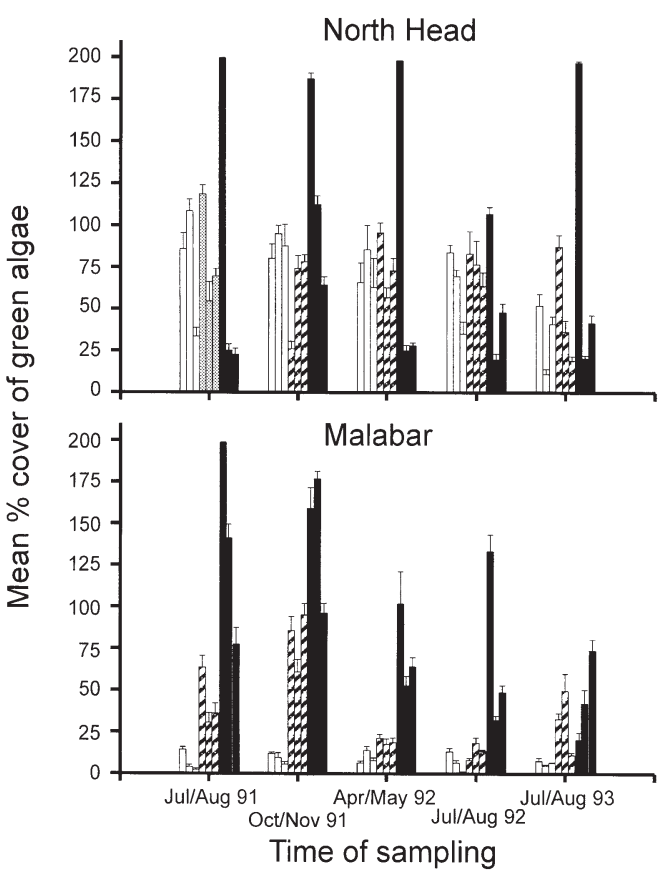

Operational Outfalls (Control)
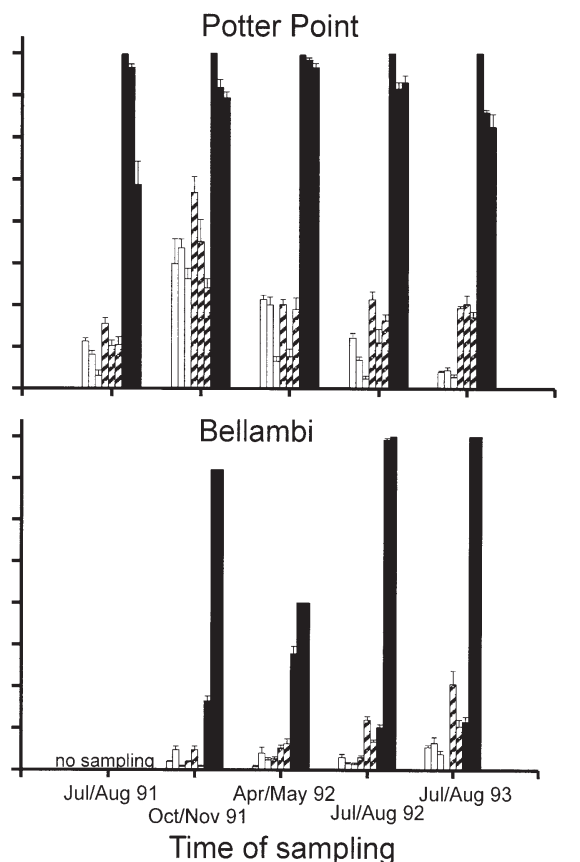

Fig. 3. Mean $(+\mathrm{SE})$ percentage cover of green algae through time in low-shore habitats for each site at the outfall (black column), and north (white column) and south (hashed column) reference locations. North Head and Malabar are the 2 experimental regions, i.e., where the outfall was decommissioned. No data could be collected at Bellambi in July/August 1991. The site closest to the point of discharge at the outfalls is the left black column for each sampling time. The data illustrated here include canopy and understorey algae of algae to increase their safety while standing there. This disturbance has been shown experimentally (Banwell 1996) to explain why there was no recovery in the number of species at these 2 sites. The great abundance of green ephemeral algae at these sites suggested that these sites are frequently disturbed. Human trampling (Brosnan \& Crumrine 1994, Banwell 1996) and baits harvested by fishermen have been shown to modify assemblages on rocky shores, including in New South Wales (Underwood \& Kennelly 1990, Kingsford et al. 1991). This disturbance was major and these sites were clearly not appropriate to include in the design.

\section{RESULTS}

Forty-six species of algae and 39 species of invertebrates were identified during this study (the most common species are listed in Table 4). Seven and 11 species decreased in their abundance at the decommissioned outfalls of North Head and Malabar, respectively. Decreases were mainly of ephemeral and opportunistic species (e.g. Chlorophycae). At least 7 species were never recorded at the outfalls throughout the experiment. More species increased than decreased in abundance at the decommissioned outfalls. Species that increased were mostly Phaeophyta and Rhodyphyta algae. Many, particularly Phaeophyta, were not present in July/August 1991, but recruited and increased in number of species and in abundance during the experiment. Twenty-one (North Head) and 15 (Malabar) species increased their abundance at these 2 outfalls (Table 4).

\section{Univariate analyses}

Low-shore areas

For the total number of species, there were significant interactions of time $\times$ site within reference locations in the 2 control regions with the operational outfalls (Table 1, Fig. 2, Potter Point and Bellambi), but not at the outfall location. Thus, there was greater variability through time between reference sites than at outfall sites. Significant interactions of time $\times$ site within the outfall locations were also identified in the 2 regions with decommissioned outfalls (Fig. 2). In the first and second samples, there were fewer species at all outfall locations (decommissioned and control) than at their respective reference locations. The total number of species remained smaller at the outfall locations than the reference locations in the control sets of data but increased through time at Malabar and North Head (decommissioned outfalls; Fig. 2). There were always significantly fewer species at the outfall site closer to the point of discharge than at the 2 others sites for North Head, Malabar and Potter Point (SNK tests on data in Fig. 2). These differences persisted for 2 yr. Because of the significance of interactions at the spatial scale of sites, there is no appropriate hypothesis for 
examining interactions at the larger spatial scale of locations (Underwood 1992).

Asymmetrical analyses of mean total percentage cover of green algae showed a significant interaction of time $\times$ site within outfalls in the 4 regions (Table 3 ). The total percentage cover of green algae was highly variable among outfall sites in 3 regions (North Head, Malabar and Bellambi). At North Head, the outfall site closest to the point of discharge had a large mean cover at all times. The other 2 sites at this outfall had a smaller cover of green algae than at most of the reference sites (Fig. 3). At Malabar, there was a greater percentage cover of green algae at the first sampling date at the 3 sites around the outfall than at any reference sites. Percentage cover decreased through time, but remained, generally greater at the outfall than at the reference sites, apart from the last date of sampling (July/August 1993; Fig. 3). Percentage cover at the outfall sites in the Potter Point region were always greater than at the respective reference sites. The same pattern was observed at the other control outfall (except for 1 site in July/August 1992 and 1993; Fig. 3). The abundance of green algae at the outfall site closest to the point of discharge at North Head was significantly greater than any outfall sites or reference sites for 4 times (except in July/August 1992; SNK tests).

\section{Midshore areas}

Sewage had little effect on the number of midshore species. The total number of midshore species varied significantly through time and site within outfall and reference locations for the 3 regions (Table 2), but there were no patterns through time. There were more species at the first sampling date for the 2 decommissioned outfalls (Fig. 4). At Potter Point, there was no pattern of difference among sites at the outfall, nor among sites at the 2 reference locations. The number of species at the outfall site closest to the point of discharge was significantly smaller (SNK tests; $\mathrm{p}<0.05$, see data in Fig. 4) than at the 2 other outfall sites at Malabar and Potter Point.

\section{Multivariate analysis}

Low-shore areas

The assemblages in the outfall sites closest to the point of discharge at North Head and Malabar differed from those in the 2 other sites at each of these outfalls in July/August 1991. In July/August 1993, assemblages at outfall sites tended to become more similar to

Table 4. Common species of macroalgae and animals that changed in abundance at the decommissioned outfalls, Malabar and North Head. Species that increased in abundance are labelled with an upward arrow $(\uparrow)$, species that decreased in abundance are labelled with a downward arrow $(\downarrow)$, and those that were not altered in abundance are represented by ' $=$ '. Species not present at every time are labelled ' $x$ '. Biota found in mid- and low-shore habitats are combined in the table

\begin{tabular}{|c|c|c|c|c|c|c|c|c|}
\hline \multirow[t]{2}{*}{ Species } & \multirow{2}{*}{$\begin{array}{l}\text { North Head } \\
\downarrow \quad=\end{array}$} & Malabar & \multirow[t]{2}{*}{ Species } & North Head & \multicolumn{4}{|c|}{ Malabar } \\
\hline & & $\downarrow \quad=$ & & $\uparrow \quad=$ & $\uparrow$ & $\downarrow$ & $=$ & $x$ \\
\hline Decreasing or equal & & & Mostly increasing & & & & & \\
\hline Cyanobacteria & $\bullet$ & $\bullet$ & Cladophora spp. & $\bullet$ & & & $\bullet$ & \\
\hline Chaetomorpha aurea & $\bullet$ & $\bullet$ & Colpomenia sinuosa & $\bullet$ & $\bullet$ & & & \\
\hline Enteromorpha spp. & $\bullet$ & $\bullet$ & Ectocarpus spp. & $\bullet$ & $\bullet$ & & & \\
\hline Ulva lactuca & $\bullet$ & - & Petalonia fascia & - & $\bullet$ & & & \\
\hline Corallina officinalis & $\bullet$ & - & Ralfsia verrucosa & $\bullet$ & $\bullet$ & & & \\
\hline Gelidium pusillum & $\bullet$ & - & Sargassum spp. & $\bullet$ & $\bullet$ & & & \\
\hline Littorina unifasciata & $\bullet$ & - & Ceramium spp. & $\bullet$ & $\bullet$ & & & \\
\hline Siphonaria virgulata & $\bullet$ & - & Dictyothamnion sp. & $\bullet$ & $\bullet$ & & & \\
\hline Tesseropora rosea & $\bullet$ & $\bullet$ & Gigartina sp. & $\bullet$ & & & & - \\
\hline Patelloida latistrigata & $\bullet$ & $\bullet$ & Gracilaria sp. & $\bullet$ & $\bullet$ & & & \\
\hline & & & Hildenbrandia prototypus & - & $\bullet$ & & & \\
\hline & & & Laurencia botyroides & - & $\bullet$ & & & \\
\hline & & & Laurencia pinnosa & - & $\bullet$ & & & \\
\hline & & & Encrusting Corallines & - & $\bullet$ & & & \\
\hline & & & Polysiphonia spp. & - & $\bullet$ & & & \\
\hline & & & Pterocladia capillacea & - & $\bullet$ & & & \\
\hline & & & Cellana tramoserica & $\bullet$ & $\bullet$ & & & \\
\hline & & & Class Polyplacophora & - & & & & $\bullet$ \\
\hline & & & Galeolaria caespitosa & - & & - & & \\
\hline & & & Kerguelenella sp. & - & & & & $\bullet$ \\
\hline & & & Montfortula rugosa & $\bullet$ & & & $\bullet$ & \\
\hline & & & Siphonaria denticulata & - & & - & & \\
\hline
\end{tabular}




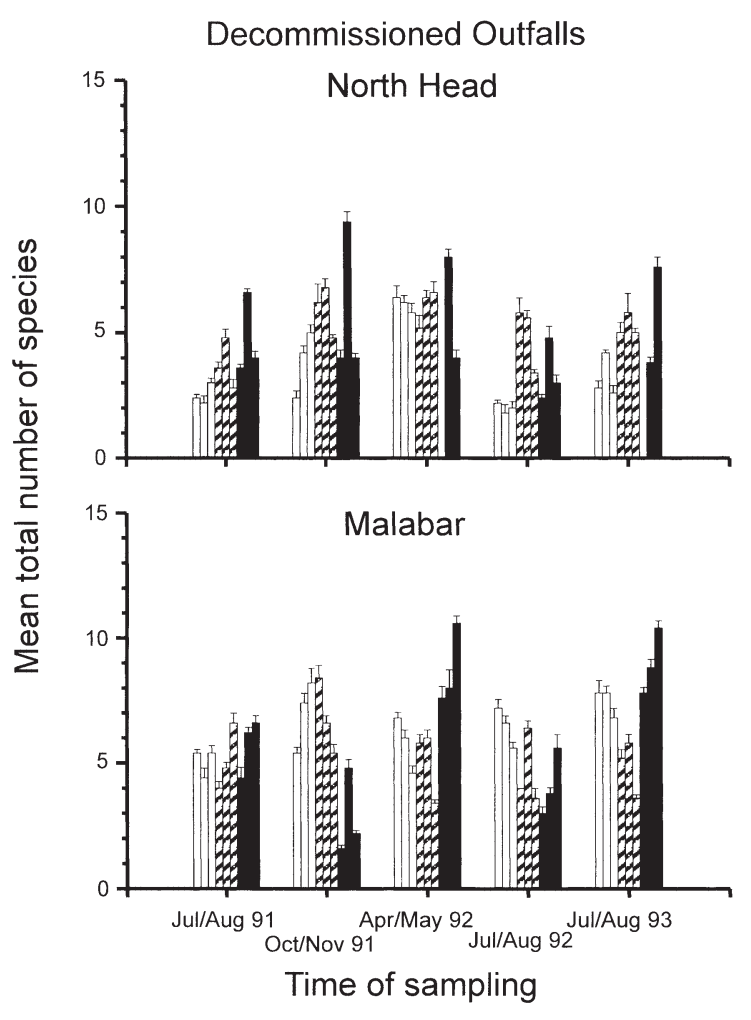

those at reference sites at North Head, but not at Malabar. At North Head, the assemblage in the outfall site closest to the pipe remained different, while the other 2 sites became similar to reference sites and clearly moved to be within the cluster of reference sites (Fig. 5a). The patterns in the 2 regions with decommissioned outfalls were supported by comparisons of the average percentage dissimilarities among the 3 locations (Table 5). Percentage dissimilarities between the outfall location at North Head and the 2 reference locations were greater in July/August 1991 than the percentage dissimilarity between the 2 reference locations. The outfall differed from other places more than due to natural spatial variation. After 2 yr (July/August 1993), the outfall sites at North Head (the closest site to the point of discharge was removed from the analysis, see 'Methods') became less dissimilar from the northern (49\%) and southern $(61 \%)$ reference locations. Even after $2 \mathrm{yr}$ of removal of sewage, the outfall location at Malabar stayed dissimilar from the reference locations (Table 5). This is also visible in the nMDS ordination (Fig. 5b)

There was a distinct separation of the outfall sites and all reference sites for

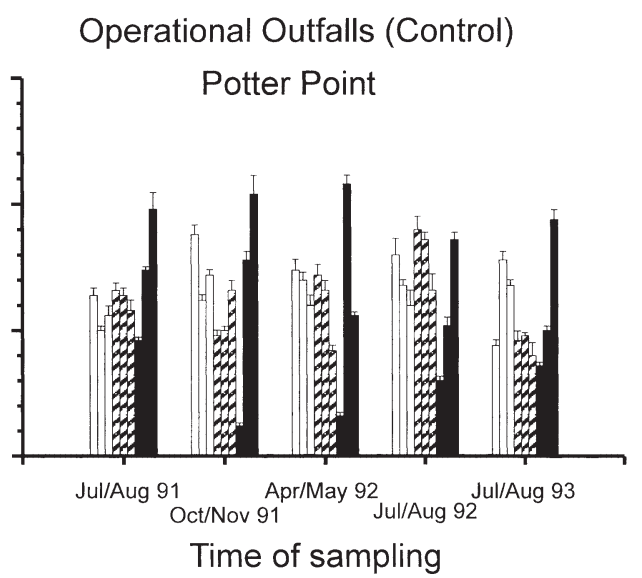

Fig. 4. Mean (+SE) number of species through time in midshore habitats for each site at the outfall (black column), and north (white column) and south (hashed column) reference locations. North Head and Malabar are the 2 experimental regions, i.e. with a decommissioned outfall. The site closest to the point of discharge at the outfalls is the left black column for each sampling time. No data were collected at Bellambi in midshore habitats

the 2 times at the operational outfalls, Potter Point and Bellambi (Fig. 5c,d). No changes through time were observed. Moreover, the percentage dissimilarities between outfall and reference locations tended to stay large and were always larger than the percentage dissimilarities between the relevant reference locations (Table 5).

Table 5. Percentage dissimilarity between locations in low-shore habitats at 2 different times for the 2 decommissioned outfalls (North Head, Malabar) and the 2 control outfalls (operational; Potter Point, Bellambi). The 2 times are the first sampling date after the closure of the outfalls and $2 \mathrm{yr}$ after the closure, respectively. The first date at Bellambi was different from that at the other outfalls

\begin{tabular}{|c|c|c|c|}
\hline & $\begin{array}{l}\text { Outfall- } \\
\text { Southern } \\
\text { reference }\end{array}$ & $\begin{array}{l}\text { Outfall- } \\
\text { Northern } \\
\text { reference }\end{array}$ & $\begin{array}{c}\text { Northern reference } \\
- \\
\text { Southern reference }\end{array}$ \\
\hline \multicolumn{4}{|c|}{ Decommissioned outfalls } \\
\hline Time 1 & 69 & 54 & 43 \\
\hline Time 5 & 61 & 49 & 60 \\
\hline \multicolumn{4}{|c|}{ Malabar } \\
\hline Time 1 & 69 & 79 & 68 \\
\hline Time 5 & 67 & 81 & 58 \\
\hline \multicolumn{4}{|c|}{ Operational outfalls (control) } \\
\hline \multicolumn{4}{|c|}{ Potter Point } \\
\hline Time 1 & 89 & 92 & 38 \\
\hline Time 5 & 86 & 96 & 46 \\
\hline \multicolumn{4}{|c|}{ Bellambi } \\
\hline Time 2 & 92 & 97 & 64 \\
\hline Time 5 & 87 & 83 & 60 \\
\hline
\end{tabular}




\section{Midshore areas}

The nMDS ordinations comparing assemblages in the midshore at outfall and reference sites at North Head, Malabar and Potter Point showed no evidence of difference at any time (Fig. 5e to g). Symbols for all sites were interspersed in July/August 1991, suggesting no important impact of the effluent on the composition of the midshore assemblages. The sites at the outfall and reference locations were also interspersed in July/ August 1993 at North Head and Potter Point. It does, however, seem that the assemblages in reference locations in the 2 experimental regions where outfalls were decommissioned changed through time (Fig. 5f,g). Furthermore, at Malabar, the sites at the outfall location diverged from the sites at the reference locations and became less dissimilar from each other by July/August 1993.

\section{DISCUSSION}

Recovery of benthic assemblages at 2 outfalls following decommissioning has been examined and compared with natural (reference) locations and with 2 operational (control) outfalls over a period of 24 mo. Numbers of species and percentage cover of green ephemeral algae changed through time at the decommissioned outfalls, but not at the reference nor at the control locations.

\section{Low-shore areas}

At the beginning of the study, assemblages at all 4 outfalls were different from those at the respective reference locations, despite there being great variability from site to site. These results are similar to those reported in other studies (Borowitzka 1972, Littler \& Murray 1975, May 1985, Brown et al. 1990, Fairweather 1990, López Gappa et al. 1993). In July/August 1993, 2 yr after the closure of 2 outfalls, a clear increase in the number of species and a decrease in the percentage cover of green algae were observed at the 2 experimental outfall locations. Furthermore, the whole assemblage had changed. In contrast, assemblages, number of species and percentage cover of green algae at the control outfalls did not change throughout the
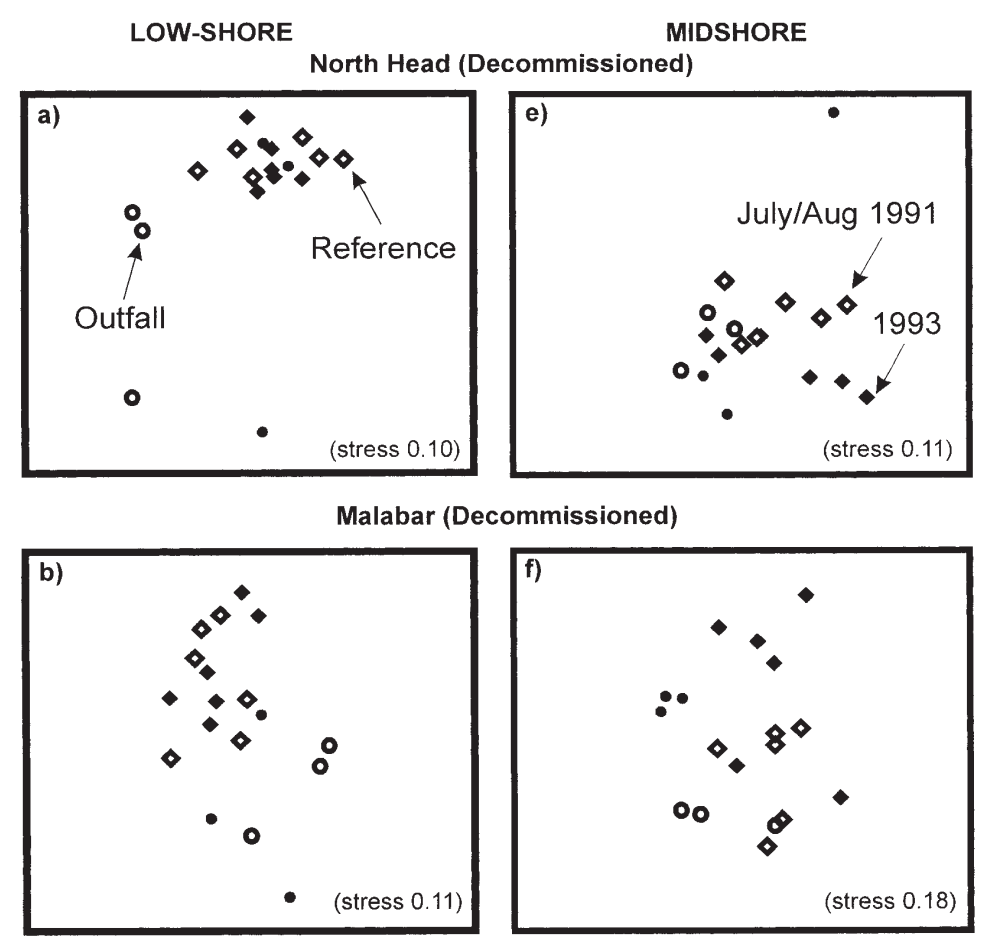

Potter Point (Control)
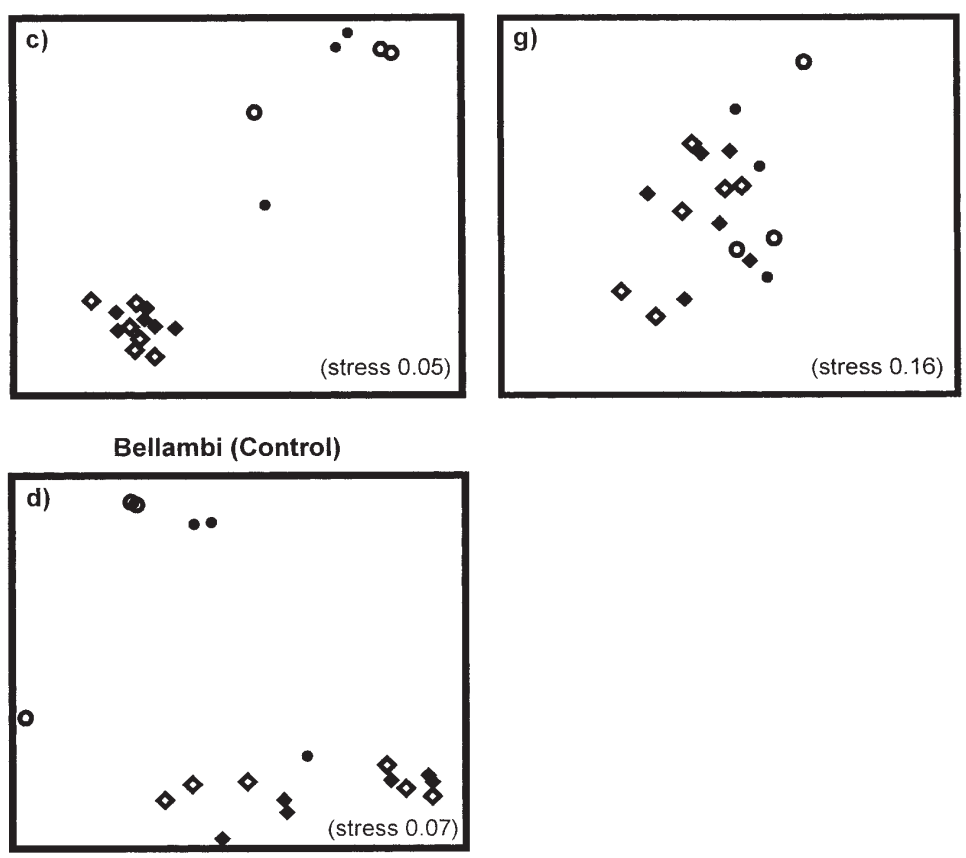

Fig. 5. Non-metric multi-dimensional scaling (nMDS) ordinations of assemblages of fauna and flora in quadrats $(n=5)$ for North Head $(a, e)$, Malabar $(b, f)$, Potter Point $(c, g)$ and Bellambi (d) comparing composition of species at 3 low-shore sites (left graphs) and 3 midshore sites (right graphs) at the outfall ( 3 circles) and at 2 reference locations (6 diamonds). The empty symbols represent samples at July/August 1991 and the filled symbols at July/August 1993. Quadrats at each site have not been distinguished; thus, $\mathrm{n}=5$ per site. Note that the sample at Bellambi in October/November 1991 was used in the nMDS ordination because there was no sample at July/August 1991 and no data for mid-intertidal habitats 
study. The results from this study support the conclusions of the studies mentioned above and provided further evidence that sewage alters the structure of assemblages in low intertidal areas.

One or only a few species of algae occupied large areas of low-shore habitat near the outfall. Such extensive mats of macroalgae (mainly green algae) associated with discharges of sewage have been described (Borowitzka 1972, Littler \& Murray 1975, May 1985, Soulsby et al. 1985, Fairweather 1990, Bellgrove et al. 1997). In this study, the percentage cover of green algae decreased dramatically at the 2 decommissioned outfalls but stayed very large at the 2 control outfalls and was small at the respective reference locations. In contrast, Soulsby et al. (1985) found that Ulva and Enteromorpha did not decrease in abundance following the closure of a sewage discharge. They suggested that the ambient nutrient regimen of the study area (Langstone Harbour, UK) naturally exceeded the requirements for growth of these macroalgae. This suggestion was supported by Montgomery et al. (1985), who showed that the nutrients in seawater entering Langstone Harbour could support the observed standing crop of macroalgae without the presence of the sewage outfall. In a long-term study, Smith et al. (1981) showed that the biomass of Ulva decreased and became less abundant after sewage was diverted at Kaneohe Bay, Hawaii. These and our results suggest that sewage outfalls provided the necessary amount of nutrients to enable these green algae to dominate the substratum. Many other models (e.g. the addition of freshwater, the abundance of grazers, rates of grazing by individual animals, etc.) must, however, be investigated before claiming that nutrients are the only factor controlling the abundance of green algae at sewage outfalls.

\section{Midshore areas}

A different pattern was apparent at midshore habitats compared with low-shore habitats. No single effect was common to all outfalls. Similar numbers of species occurred at reference and outfall locations at all times (before and up to $2 \mathrm{yr}$ after decommissioning) suggesting that the outfalls had little impact on organisms in midshore areas. Furthermore, the whole assemblages in outfall locations and their respective reference locations did not differ before the closure of the outfalls. There was no evidence that the midshore assemblages and number of species at the outfall locations differed significantly from those at reference locations. Spatial and temporal patterns were variable more among sites within any location than between locations (reference versus outfall or refer- ence versus reference). This finding is in contrast with most of the studies (except Roberts \& Scanes 2000) on the effects of sewage on subtidal and intertidal assemblages in New South Wales, most of which has shown a localised effect (May 1985, Fairweather 1990, Smith 1996). Underwood \& Chapman (1996) observed a similar pattern to the results described here in subtidal habitats close to an outfall. Their study and the present study began between 4 and 6 mo after the closure of outfalls. Underwood \& Chapman (1996) suggested that organisms were not stressed because wave action, tides and currents continuously removed effluents. In contrast, Roberts et al. (1998) described rapid changes (within 3 mo) following the discharge of sewage effluent in a similar subtidal habitat. Perhaps midshore organisms were not exposed as often or for as long as were organisms lower on the shore to effluents because all discharges were below low-tide levels. During high tide, the sewage would be diluted. Data before the outfalls were decommissioned indicate no persistent influence of sewage on midshore assemblages (unpubl. data)

\section{Recovery}

The present study defined recovery as convergence of the various variables in affected locations to the values in reference locations. From this study, the overall conclusion is that recovery of assemblages occurred in most areas of the low-shore at North Head and Malabar outfalls following their decommissioning. At the 2 control outfalls, no changes were observed. In general, the detection of whether recovery has occurred can be problematic (Fairweather 1993, McDonald \& Erickson 1994, Chapman 1999, Underwood \& Chapman 1999, Underwood 2000) with regard to the time-course involved and the selection of the appropriate reference and control locations. Furthermore, the level of acceptable recovery has generally not been well defined. McDonald \& Erickson (1994) highlighted the advantages of using bioequivalence to test whether recovery has occurred between treated areas and reference areas, but this procedure is not common in biological sciences. Moreover, studies designed to detect the influence of human activities must include replication at relevant spatial and temporal scales. This can be achieved by hierarchical sampling, with nested designs such as that used in this study (Underwood 1991, 1992, 1993, 2000). Data need not be collected before an impact, although it is better to be able to do so (Green 1979, Underwood 1994). When it is impossible to collect prior data, subsequent samples 
must be compared with data collected at appropriate reference locations (Bernstein \& Zalinski 1983, Underwood 1994). When using asymmetrical designs as advocated by various authors (Underwood 1994, Otway 1995b, Roberts et al. 1998), the number of reference locations sampled must be considered. The present study confirms the importance of making comparisons between a contaminated location and more than 1 reference area. Chapman (1999) suggested that restoration (i.e., after closure of the outfall) cannot be properly assessed without multiple control locations (here, outfalls that continued to operate) and reference locations (ideally, natural undisturbed areas). The use of 2 control outfalls in this study increased the reliability of our finding that the closure of 2 effluents resulted in recovery of intertidal assemblages (Chapman 1999). This study was designed to be able to test the hypothesis that the number of species or abundances of algae would recover after the closure of the outfalls and that such changes would not be due to natural variability or some other larger-scale influences.

It had been predicted that decommissioning 2 outfalls would lead to recovery of the intertidal benthic assemblages at these outfalls. The decommissioning of the outfall led to a recovery (increase in number of species similar to the reference locations and a decrease in abundance of green algae), except at sites where fishermen removed the algae. The primary aim of the closure of the outfalls was to reduce the effluent into beaches for human health issues, but it was also important to test the stated predictions about the recovery of intertidal organisms. If the aim of managerial decisions is recovery, further action is needed to manage fishermen. This requires careful designs to show what happens following changed management of an area. The design to follow the recovery in our study was replicated at 2 decommissioned outfalls and control areas (operational outfalls), each with replicated reference areas and assessments at a hierarchy of spatial scales to allow valid conclusions to be made. In general, spatial and temporal variations must be estimated properly to discern the environmental signal that would identify the real response to a change in management. Otherwise confusion will continue to reign.

Acknowledgements. We thank V. Mathews for help with the graphics, W. Green for help with analyses, Drs C. W. McKindsey, M. G. Hoskin and M. G. Chapman, and 4 anonymous referees for constructive advice on earlier drafts of the manuscript. P.A. was supported by an NSERC (Natural Sciences and Engineering Research Council of Canada) Postdoctoral Fellowship. The preparation of the paper was funded by the Australian Research Council through the Centre for Research on Ecological Impacts of Coastal Cities.

\section{LITERATURE CITED}

Ajani PA, Roberts DE, Smith AK, Krogh M (1999) The effect of sewage on two bioindicators at Port Stephens, New South Wales, Australia. Ecotoxicology 8:253-267

Axelrad DM, Poore GCB, Arnott GH, Bauld J, Brown V, Edwards RRC, Hickman NJ (1981) The effects of treated sewage discharge on the biota of Port Phillip Bay, Victoria, Australia. In: Neilson BJ, Cronin LE (eds) Estuaries and nutrients. Humana Press, Clifton, p 279-306

Banwell K (1996) Structure of intertidal rocky shore assemblages following the removal of sewage. MSc thesis, University of Sydney

Bellgrove A, Clayton MN, Quinn GP (1997) Effects of secondarily treated sewage effluent on intertidal macroalgae recruitment processes. Mar Freshw Res 48:137-146

Bernstein BB, Zalinski J (1983) An optimal sampling design and power tests for environmental biologist. J Environ Manage 65:35-43

Borowitzka MA (1972) Intertidal algal species diversity and the effect of pollution. Aust J Mar Freshw Res 23:73-84

Brosnan DM, Crumrine LL (1994) Effects of human trampling on marine rocky shore communities. J Exp Mar Biol Ecol 177:79-97

Brown VB, Davies SA, Synnot RN (1990) Long-term monitoring of the effects of treated sewage effluent on the intertidal macroalgal community near Cape Schanck, Victoria, Australia. Bot Mar 33:85-98

Calcagno JA, Gappa JL, Tablado A (1997) Growth and production of the barnacle Balanus amphitrite in an intertidal area affected by sewage pollution. J Crustac Biol 17: $417-423$

Calcagno JA, Gappa JL, Tablado A (1998) Population dynamics of the barnacle Balanus amphitrite in an intertidal area affected by sewage pollution. J Crustac Biol 18:128-137

CDM (1989) Review of Sydney's beach protection programme. Camp, Dresser \& McKee International Inc, Cambridge, MA

Chapman MG (1999) Improving sampling designs for measuring restoration in aquatic habitats. J Aquat Ecosyst Stress Recov 6:235-251

Chapman MG, Underwood AJ, Skilleter GA (1995) Variability at different spatial scales between a subtidal assemblage exposed to the discharge of sewage and two control assemblages. J Exp Mar Biol Ecol 189:103-122

Clarke KR (1993) Non-parametric multivariate analyses of changes in community structure. Aust J Ecol 18:117-143

Clayton MN, King RJ (1990) Biology of marine plants. Longman Cheshire, Melbourne

Eberhert LL, Thomas JM (1991) Designing environmental field studies. Ecol Monogr 61:53-73

Fairweather PG (1990) Sewage and the biota on seashores: assessment of impact in relation to natural variability. Environ Monit Assess 14:197-210

Fairweather PG (1993) Links between ecology and ecophilosophy, ethics and the requirements of environmental management. Aust J Ecol 18:3-19

Glasby TM (1997) Analysing data from post-impact studies using asymmetrical analyses of variance: a case study of epibiota on marinas. Aust J Ecol 22:448-459

Green RH (1979) Sampling design and statistical methods for environmental biologists. Wiley, Chichester

Kingsford MJ, Underwood AJ, Kennelly SJ (1991) Humans as predators on rocky reefs in New South Wales, Australia. Mar Ecol Prog Ser 72:1-14

Littler MM, Murray SN (1975) Impact of sewage on the distribution, abundance and community structure of rocky intertidal macro-organisms. Mar Biol 30:277-291 
López Gappa JJ, Tablado A, Magaldi NH (1990) Influence of sewage pollution on a rocky intertidal community dominated by the mytilid Brachidontes rodriguezi. Mar Ecol Prog Ser 63:163-175

López Gappa JJ, Tablado A, Magaldi NH (1993) Seasonal changes in an intertidal community affected by sewage pollution. Environ Pollut 82:157-165

López-Rodriguez MC, Barbara I, Perez-Cirera JL (1999) Effects of pollution on Fucus vesiculosus communities on the Northwest Iberian Atlantic coast. Ophelia 51:129-141

May V (1985) Observations on algal floras close to two sewerage outlets. Cunninghamia 1:385-394

McDonald LL, Erickson WP (1994) Testing for bioequivalence in field studies: has a disturbed sites been adequately reclaimed? In: Fletcher DJ, Manly BFJ (eds) Statistics in ecology and environmental monitoring. University of Otago Press, Dunedin, p 183-197

Montgomery HAC, Soulsby PG, Hart IC, Wright SL (1985) Investigation of a eutrophic tidal basin II-Nutrients and environmental aspects. Mar Environ Res 15 285-302

Otway NM (1995a) Assessing impacts of deepwater sewage disposal: a case study from New South Wales, Australia. Mar Pollut Bull 31:347-354

Otway NM (1995b) Environmental problems due to the disposal of waste. 2. Disposal of waste. In: Underwood AJ, Chapman MG (eds) Coastal marine ecology of temperate Australia. New South Wale University Press, Sydney, p 304-310

Pearson TH, Rosenberg R (1978) Macrobenthic succession in relation to organic enrichment and pollution of the marine environment. Annu Rev Oceanogr Mar Biol 16:229-311

Roberts DE, Scanes PR (2000) Spatial patterns in the macrobenthic assemblages inhabiting kelp (Ecklonia radiata) forests exposed to sewage effluent. Aust J Ecotoxicol 5: 89-102

Roberts DE, Smith A, Ajani P, Davis AR (1998) Rapid changes in encrusting marine assemblages exposed to anthropogenic point-source pollution: a 'Beyond BACI' approach. Mar Ecol Prog Ser 163:213-224

Smith AK, Ajani PA, Roberts DE (1999) Spatial and temporal variation in fish assemblages exposed to sewage and implications for management. Mar Environ Res 47: 241-260

Smith SDA (1996) The effects of domestic sewage effluent on marine communities at Coffs Harbour, New South Wales, Australia. Mar Pollut Bull 33:7-12

Editorial responsibility: Otto Kinne (Editor),

Oldendorf/Luhe, Germany
Smith SV, Kimmerer WJ, Laws EA, Brock RE, Walsh TW (1981) Kaneohe Bay sewage diversion experiment: perspectives on ecosystem responses to nutritional perturbation. Pac Sci 35:279-395

Soulsby PG, Lowthion D, Houston MA, Montgomery HAC (1985) The role of sewage effluent in the accumulation of macroalgal mats on intertidal mudflats in two basins in Southern England. Neth J Sea Res 19:257-263

Taylor LA, Chapman PM, Miller RA, Pym RV (1998) The effects of untreated municipal sewage discharge to the marine environment off Victoria, British Columbia, Canada. Water Sci Technol 38:285-292

Underwood AJ (1991) Beyond BACI: experimental designs for detecting human environmental impacts on temporal variations in natural populations. Aust J Mar Freshw Res 42:569-587

Underwood AJ (1992) Beyond BACI: the detection of environmental impacts on populations in the real, but variable, world. J Exp Mar Biol Ecol 161:145-178

Underwood AJ (1993) The mechanics of spatially replicated sampling programmes to detect environmental impacts in a variable world. Aust J Ecol 18:99-116

Underwood AJ (1994) On beyond BACI: sampling designs that might reliably detect environmental disturbances. Ecol Appl 4:3-15

Underwood AJ (1996) Detection, interpretation, prediction and management of environmental disturbances: some roles for experimental marine ecology. J Exp Mar Biol Ecol 200:1-27

Underwood AJ (2000) Trying to detect impacts in marine habitats: comparisons with suitable reference areas. In: Sparks T (ed) Statistics in ecotoxicology. John Wiley \& Sons, Toronto, p 279-308

Underwood AJ, Chapman MG (1996) Subtidal assemblages on rocky reefs at a cliff-face sewage outfall (North Head, Sydney, Australia): what happened when the outfall was turned off? Mar Pollut Bull 33:7-12

Underwood AJ, Chapman MG (1999) The role of ecology in coastal zone management: perspectives from South-East Australia. In: Salomons W, Turner RK, de Lacerda LD, Ramachandran S (eds) Perspectives on integrated coastal zone management. Springer, Berlin, p 99-128

Underwood AJ, Kennelly SJ (1990) Pilot studies for the designs of surveys of human disurbance of intertidal habitats in New South Wales. Aust J Mar Freshw Res 41: 165-173

Submitted: September 25, 2000; Accepted: March 22, 2001 Proofs received from author(s): October 18, 2001 